\title{
A MORPHOLOGICAL STUDY OF PALLAVICINIA
}

LYELLII

CONTRIBUTIONS FROM THE HULL BOTANICAL LABORATORY 245

ARTHUR W. HAUPT

(WITH PLATES XX-XXIV)

Pallavicinia, according to SchiffNeR's (12) census, is represented by 2 I species, most of which are tropical. Later, SCHIFFNER (13) added 2 European species to his former list, thus making 5 species indigenous to the Old World. Pallavicinia Lyellii is found in the more humid parts of both the Northern and Southern Hemispheres; it grows near Chicago in a peat bog at Mineral Springs, Indiana. Pallavicinia, Symphyogyna, and Monoclea are included in the family Leptotheceae. The affinities of the Japanese genus Makinoa, described by MryaKe (9), seem to place it in this family, as is done by Cavers. The disposition of Monoclea is a matter of great difference of opinion, some, as JoHnson (6), placing it with the Marchantiales. There can be no doubt, however, as to the closeness of relationship between Pallavicinia and Symphyogyna, regardless of the classification of the other genera of the family.

Cavers (2) divides Pallavicinia into the two genera of GotTsche: Blyttia and Mörckia. According to the Vienna code, the older name Pallavicinia must be retained; if SCHIFFNER's subgenus Mörckia (Gott.) is to be elevated to generic rank, it must not be done at the expense of the name Pallavicinia. STEPHANI (14) separates the genus into the 2 sections Procumbentes and DeNDROIDEAE; SCHIMPER, into the subgenera Eupallavicinia, Mörckia, and Mittenia. Pallavicinia Lyellii belongs to the Procumbentes or Eupallavicinia division.

\section{Material}

Most of the material studied was collected by Mr. R. P. MAson, at Columbiana, Alabama, to whom the writer is greatly indebted. Additional material was obtained by Dr. W. J. G. LAND, at Mineral Springs, Indiana. Most of the slides illustrating the antheridial. 
series were made by Dr. LAND and Mr. MAson, while those showing the development of the archegonium and the sporophyte were prepared by the writer.

\section{Thallus}

The vegetative body of Pallavicinia Lyellii consists of a creeping, prostrate thallus $4-5 \mathrm{~mm}$. wide, composed of a midrib with thin, one-layered, lateral wings, and bearing rhizoids. The margin is somewhat undulate, with no indications of hooked appendages as in $P$. longispina, $P$. xiphioides, or P. Zollengeri. The midrib consists of pitted conducting cells with thickened walls, which become differentiated directly behind the apical cell (fig. 45); about 70 to 80 may be seen in cross-section (fig. 44). TANSLEy and CHICK (I5) made a careful study of these cells and showed by eosin solutions that they conduct water. Miss McCoRMick (8) demonstrated that in Symphyogyna aspera they are composed of pectose. These conducting cells are also found in Hymenophyton.

Growth of the thallus is by means of a dolabrate (zweischneidig) apical cell (fig. 43). This feature seems to have first been observed by LeITGEB (7), who discusses at considerable length apical growth and the development of the thallus body. Two-celled mucilage hairs arise both dorsally and ventrally in connection with the apical cell, strongly resembling sex organ initials.

Branching is of two kinds: apical, from the apical cell; and endogenous, from ventral adventitious shoots. Material showing the origin of the latter was lacking and hence LEITGEB's statement, that the conducting tissue of the ventral branch is not continuous in origin with the central cells of the main thallus, could not be verified.

\section{Sex organs}

The gametophytes of Pallavicinia Lyellii are strictly dioecious, the male plants being slightly more slender than the female. Both antheridia and archegonia are dorsal, the former lying in 2 parallel rows on each side of the midrib, and the latter remaining directly above the midrib, slightly raised on a pad. Two involucres are present, the outer one corresponding to that of Symphyogyna and Monoclea; the inner one, or perianth, is characteristic of Pallavicinia, Podomitrium, and Calycularia. 


\section{ANTHERIDIA}

The antheridia originate in close proximity to the apical cell, arising in acropetal succession on the dorsal side of the thallus, usually singly, but occasionally two or three together. With further apical divisions they come to lie in 2 parallel rows on each side of the midrib, slightly sunken in the thallus by the development, from behind, of an involucral upgrowth. The mature antheridia are spherical and short-stalked and point diagonally outward and upward, each one being separated from the one preceding it by sterile tissue (fig. I).

An antheridium initial appears as a papillate projection above the surface of the thallus, resembling closely one of the mucilage hairs with which it is associated. A transverse wall appears, dividing the initial into 2 nearly equal segments, the basal one remaining in the thallus and the outer one projecting above the surface of the thallus (fig. 2). The outer cell divides transversely into equal segments, forming a primary stalk cell and a primary antheridial cell (fig. 3 ). With further increase in size, the latter divides by a median vertical wall, followed rapidly by a similar division in the stalk cell (fig. 4). One or two further transverse divisions complete the stalk, while a periclinal wall cuts off a peripheral cell on one side of the antheridium, intersecting the first vertical wall near the top (fig. 5). A corresponding periclinal wall appears on the other side, followed by 2 more walls at right angles to the first two, intersecting both these and the first median division. As a result, 4 primary wall cells inclose 2 central cells, the entire structure being bisected by the original vertical wall. At this stage the involucre appears as an upgrowth of the thallus behind the young antheridium (fig. 9). It is built up by basal growth, and by the time the antheridium is mature, it consists of a scalelike sheath, 6-10 cells in length. Whether these coverings are to be regarded as the beginnings of true foliar structures or merely as dorsal upgrowths of the thallus seems to be entirely a matter of opinion. If the complete involucre of Pellia be taken as representing the initial stage, a failure of the forward portion to develop would result in the precise condition found in Pallavicinia. Sphaerocarpus, perhaps, represents an intermediate stage, as here the development of 
the forward portion is slightly arrested, resulting in greater protection from behind. It seems a perfectly logical step from the antheridial condition in Pallavicinia to that of one of the simpler acrogynous Jungermanniales, such as Porella, in which case the coverings are longer and more leaflike in appearance.

Further growth of the antheridium corresponds to that of the other anacrogynous Jungermanniales. During the 2 or 3 mitoses preceding the formation of the sperm mother cells, the cell walls of the spermatogenous mass gradually disappear and abundant mucilage surrounds the dividing protoplasts. Walls around the sperm mother cells were evident, but it could not be determined whether they had been laid down by the mother cell protoplasts, or represented the remaining cellulose which had not become mucilage.

- The sperm mother cells produce two sperms, each with little cytoplasm, and separated by a very thin wall. The nuclei were so small that it was not possible to study the details of spermatogenesis. The development is probably the same as that of Pallavicinia Zollengeri, described by CAMPBELL and Williams (I).

\section{ARCHEGONIA}

The earliest stages in the development of the archegonial group were not present in the material studied. A group of initials seems to arise a short distance back of the apical cell, directly above the midrib on the dorsal side of the thallus. This group presently becomes surrounded by an annular upgrowth of the thallus, which becomes the involucre. The apical cell is not checked by the development of the archegonia, but continues the growth of the thallus, so that often 2 or 3 groups may be produced along the midrib, separated by sterile areas. The archegonial group continues to produce archegonia up to the time of fertilization, many young sex organs frequently being found with mature ones. Two-celled mucilage hairs are abundantly produced. Twenty to 30 archegonia usually occur in a group.

The archegonium, like the antheridium, arises as a papillate projection from one of the cells inclosed by the involucre. A transverse wall cuts off a basal cell, which remains within the thallus, and an outer cell, which is freely exposed (fig. I0). The latter 
undergoes 2 transverse divisions, the sequence of which could not be determined; the lower 2 cells form the stalk and the upper one the archegonium proper, agreeing in this repsect with Pallavicinia radiculosa, described by CAMPBELL and Williams (figs. I I,-I2). Three vertical divisions occur in the archegonium proper, according to the manner of all anacrogynous Jungermanniales, resulting in the formation of an inner cell surrounded by 3 primary wall cells, 2 of which can be seen in a longitudinal section (fig. 12). A transverse division in the upper part of the inner cell results in the formation of a central cell and a cap cell (fig. I3), which later undergoes further division, contributing to the development of the neck.

Following the formation of the cap cell, the central cell divides into two nearly equal cells (fig. I4), the upper being the primary neck canal cell, and the lower the primary ventral cell. The development of the axial row usually precedes the division of the primary ventral cell, although frequently mitoses can be seen in the neck cells after the formation of the ventral canal cell and egg (fig. 22). In most cases about ro neck canal cells were seen; sometimes, however, as many as 18 are formed (fig. 25). The primary ventral cell, by a transverse division, produces a ventral canal cell and egg which are almost equal in size (fig. I8). The neck canal cells are surrounded by a jacket of 5 cells, although frequently one or more of these may divide (fig. 24).

Very soon after the division of the ventral cell the ventral canal cell becomes mucilaginous and finally the entire axial row is broken down (figs. I9, 20). The egg nucleus at this stage is very prominent, the dense nucleolus being surrounded by extremely light nucleoplasm. With the preparation of the egg for fertilization, the wall of the venter becomes 2-layered, the first divisions occurring as the ventral canal cell begins to disorganize. The mature archegonium is characterized by a rather long slender stalk, a narrow venter, and a long twisted neck; it closely resembles an archegonium of Symphyogyna.

Just before the older archegonia in a group mature the characteristic perianth appears immediately within the involucre. It attains a height of several cells (fig. 2I), but as soon as fertilization is effected, it is greatly stimulated, and develops, by basal inter- 
calary divisions, much in excess of the young sporophyte. The perianth keeps pace with the elongation of the embryo, reaching a maximum height of about $5 \mathrm{~mm}$. At the time immediately preceding spore disperal, the seta shows remarkable growth, becoming $25^{-27} \mathrm{~mm}$. long. The perianth attains a thickness of 3 or 4 cells, as seen in cross-section, and becomes fringed around the top. The involucre, on the other hand, does not at any time exceed the height of the archegonia and it is related to their protection in the same way that the perianth is associated with the protection of the sporophyte. With the development of the perianth, following fertilization, the involucre becomes flaring and denticulate around the top.

After fertilization the egg cytoplasm becomes denser and a heavy wall is laid down around the protoplast, thus making it independent of the tissue of the archegonium.

\section{Sporophyte}

The youngest sporophyte which was observed consisted of a tier of 4 cells (fig. 26). The first division is followed by a transverse wall in the lower segment and then by a similar wall in the upper segment. A vertical division then occurs in the upper half of the embryo (figs. 27, 28), followed by vertical and transverse walls. The lower half of the embryo usually undergoes one vertical division, but contributes nothing to the development of the foot, seta, or capsule (fig. 29). Half of the potentially sporogenous tissue derived from the fertilized egg thus is diverted for haustorial purposes. A similar situation has been observed by Miss CLAPP (3) in Aneura pinguis, and by CAMpbell and Williams in Pallavicinia Zollengeri. The relation between the early divisions in the embryo and the development of the 3 regions of the sporophyte could not be ascertained, material being wanting. The differentiation of the sporogenous tissue, however, occurs relatively late. According to FARMER (4), the young embryo of Pallavicinia decipiens consists of a tier of 3 cells, the upper segment forming the capsule, the middle segment the seta and part of the foot, and the lower segment the rest of the foot.

With the growth of the embryo, the venter of the archegonium becomes a calyptra 4 or 5 cells in thickness, which grows in length 
with the sporophyte. The calyptra is notably smaller than in Symphyogyna and Monoclea, presumably because its protective function is performed by the perianth. The non-functioning archegonia are carried up with the tissue of the calyptra but do not persist long. Only one embryo was seen developing in an archegonial group, although it is possible that more than one may be formed, as in Symphyogyna aspera.

The differentiation of the spores and elaters occurs late in the development of the sporophyte, and follows precisely the method of Symphyogyna aspera, as described by Miss McCormick (figs. 3338). Material showing the reduction division in the formation of spores was entirely absent in the material studied. FARMER (5), in his study of this process in Pellia epiphylla and Pallavicinia decipiens, noted the presence of a quadripolar spindle in the spore mother cell. MOORE (Io, II), however, working with Pallavicinia Lyellii, failed to find such a condition, but observed that the two divisions take place in very rapid sequence, giving the appearance of such a spindle as FARMER describes.

The mature capsule is cylindrical, is inclosed by a sterile wall one cell thick, and bears spiral thickenings (figs. 32, 39). The sterile cap at the apex of the mature capsule is not so prominent as in Symphyogyna, being only 5 or 6 cells thick, and bears no relation to the elaters. The mature sporophyte reaches a length of $40 \mathrm{~mm}$., the capsule being about $3.5 \mathrm{~mm}$. long. Dehiscence is by means of 4 longitudinal slits which remain attached at the top. The foot is wedge-shaped as in Symphyogyna, but it occasionally shows a resemblance to the anchor-like foot of Marchantia (figs. 4I, 42). The mature elaters reach a length of nearly $0.3 \mathrm{~mm}$., and are furnished with a double spiral band. The spores are about $0.015 \mathrm{~mm}$. in diameter, the wall being conspicuously reticulate (fig. 38 ).

\section{Summary}

I. Pallavicinia Lyellii belongs to the subgenus Eupallavicinia, the vegetative body consisting of a single prostrate portion.

2. The apical cell is of the dolabrate type. Branching is both apical and adventitious. 
3. Pallavicinia Lyellii, like the other species of the genus, is strictly dioecious.

4. The antheridia occur in 2 parallel rows on each side of the midrib, and are protected from behind by an involucral upgrowth. Their development, with minor variations, follows the type for the anacrogynous Jungermanniales.

5. The archegonia are in dorsal groups and are surrounded by an involucre and a perianth, the latter remaining inconspicuous until after fertilization.

6. The young archegonial stalk consists of 2 cells. The egg is small and the neck long and twisted.

7. The lower half of the fertilized egg becomes a haustorial organ and contributes nothing to the development of the foot, seta, or capsule.

8. The calyptra is 4 or 5 cells in thickness, in this respect differing from that of Symphyogyna.

9. The differentiation of the spores and elaters occurs relatively late in the development of the sporophyte, and follows the method of Symphyogyna.

Io. A sterile cap is present at the apex of the capsule and remains intact in dehiscence, which is accomplished by means of 4 longitudinal slits.

To Dr. W. J. G. LaND, under whose direction the study was undertaken, the writer is indebted for many helpful suggestions and criticisms.

University of Chicago

\section{LITERATURE CITED}

I. Campbell, D. H., and Williams, Florence, A morphological study of some members of the genus Pallavicinia. Leland Stanford Junior Univ. Pub., Univ. Series, pp. 44. I9I4.

2. CAVERS, F., The interrelationships of the Bryophyta. III. Anacrogynous Jungermanniales. New Phytol. 9: 197-234. I910.

3. Clapp, Grace L., The life history of Aneura pinguis. Bor. Gaz. 54:177I90. I9I2.

4. Farmer, J. Bretland, Studies in Hepaticae; on Pallavicinia decipiens Mitten. Ann. Botany 8:35-52. 1894 . 
5. FARMer, J. Bertrand, The quadripolar spindle in the spore mother cell of Pellia epiphylla. Ibid. 15:431-433. I90I.

6. Johnson, D. S., The development and relationship of Monoclea. Вот. GAZ. 38: $185^{-205}$. 1904 .

7. Leitgeb, Hubert, Untersuchungen über die Lebermoose, vol. 3, Die frondosen Jungermannien. Leipzig. 1877 .

8. McCormick, Florence A., A study of Symphyogyna aspera. Bot. Gaz. 58:40I-4I8. I9I4.

9. Mryake, K., Makinoa, a new genus of Hepaticae. Bot. Mag. Tokyo 13: 2I-24. I899.

10. Moore, A. C., The mitoses in the spore mother cell of Pallavicinia. Вот. GAZ. 36:384-388. I903.

I1. - Sporogenesis in Pallavicinia. Ibid. 40:8I-96. I905.

I2. Schiffner, V., Hepaticae in Engler and Prantl's Natürlichen Pflanzenfamilien $\mathrm{r}$ : I-I44. I909.

13. - Untersuchungen über Mörckia Flotowiana und über das Verhältnis der Gattungen Mörckia Gott. und Calycularia Mitt. zu einander. Oesterr. Bot. Zeitschr. 5I:4I-5I. I90I.

14. Stephani, F., Species Hepaticarum. Memoires de L'Herbier Boissier. I900.

15. Tansley, A. G., and Chick, Edith, Notes on the conducting tissue system in Bryophyta. Ann. Botany 15: 1-38. I90I.

\section{EXPLANATION OF PLATES XX-XXIV}

\section{Pallavicinia Lyellii}

FIG. I. - Thallus with antheridia; $\times$ ro.

Figs. 2-7.-Stages in development of antheridium; $\times 630$.

FIG. 8.-Older antheridium; $\times 62$.

FIG. 9. - Young antheridium with involucre; $X_{4} 6$.

FIGS. 10-20.-Stages in development of archegonium; $X_{520}$

FIG. 21. - Perianth before fertilization; $\times_{5}$.

FIG. 22.-Archegonium showing elongation of neck; $X_{5}$.

Fig. 23.-Median longitudinal section of archegonial group; $X_{25}$.

FIG. 24.-Cross-section of neck of archegonium; $\times_{52}$.

FIG. 25.-Mature archegonium showing 18 neck canal cells; $\times_{260}$.

FIGS. 26-28. - Stages in development of embryo; $\times 5^{20}$.

FIG. 29.-Older embryo showing haustorial cells and differentiation of sporogenous tissue; $\times_{50}$; sketch of same stage; $\times 8$.

FIG. 30.-Development of sporogenous tissue; $X_{50}$; sketch of same stage; $\times 8$.

FIG. 31.-Sketch of older sporophyte; $\times 6$.

FIG. 32 .- Sporophyte containing mature spores and elaters; $\times 6$.

FIGS. $33-37$.- Stages in development of spore mother cells; $X_{52}$. 

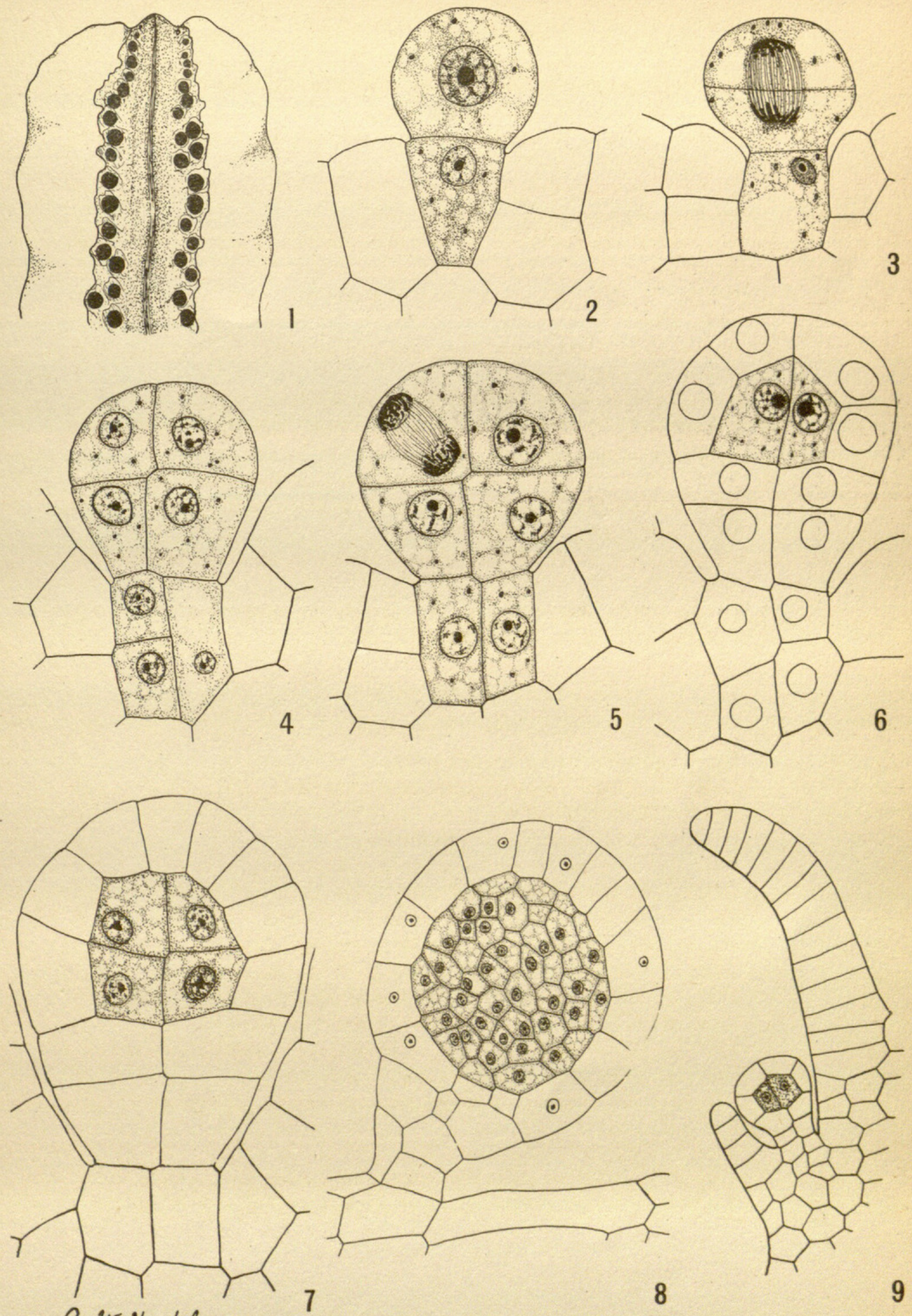

a.w.st. del.

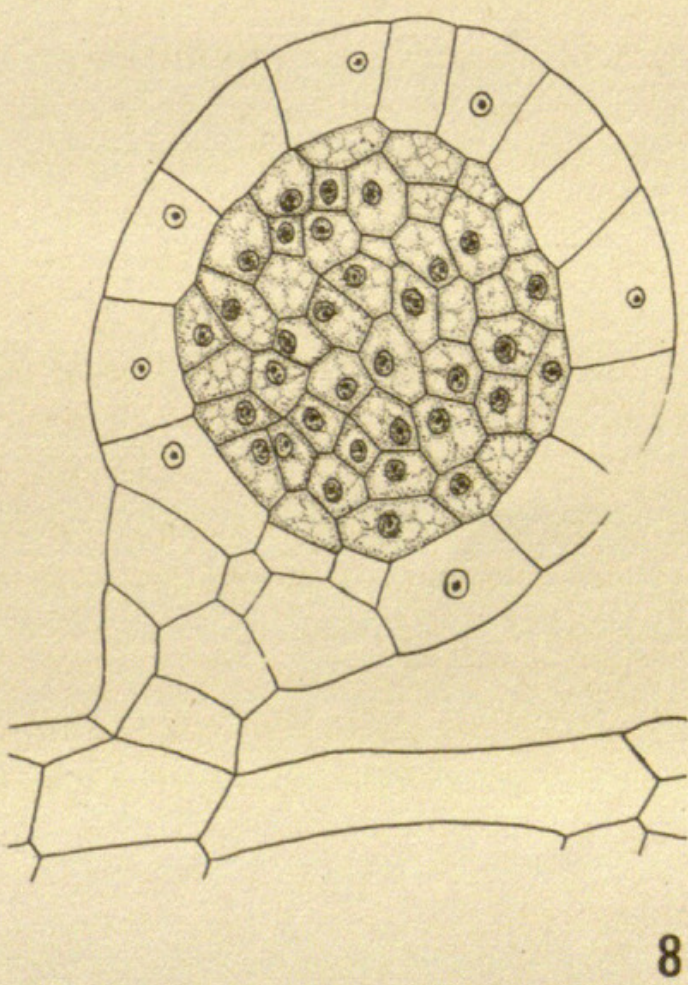




\section{$2 \mathrm{BHL}$ Biodiversity Heritage Library}

Haupt, Arthur W . 1918. "A Morphological Study of Pallavicinia lyellii." Botanical gazette 66(6), 524-533. https://doi.org/10.1086/332375.

View This Item Online: https://www.biodiversitylibrary.org/item/109341

DOI: https://doi.org/10.1086/332375

Permalink: https://www.biodiversitylibrary.org/partpdf/224092

\section{Holding Institution}

Missouri Botanical Garden, Peter H. Raven Library

\section{Sponsored by}

Missouri Botanical Garden

\section{Copyright \& Reuse}

Copyright Status: Public domain. The BHL considers that this work is no longer under copyright protection.

This document was created from content at the Biodiversity Heritage Library, the world's largest open access digital library for biodiversity literature and archives. Visit BHL at https://www.biodiversitylibrary.org. 